\title{
Praca dla Polski. Działalność niepodległościowa oraz udział Błażeja Stolarskiego w odbudowie struktur państwowych w latach 1914-1922
}

\author{
Work for Poland. Błażej Stolarski's \\ Independence Activity and Participation in the \\ Reconstruction of State Structures Between 1914-1922
}

Gdy po zbrojnym zrywie niepodległościowym i walkach o ukształtowanie granic następowała refleksja, jak zbudować od podstaw życie społeczne, polityczne i gospodarcze w jednym państwowym organizmie, na scenę historyczną wkroczyli nowi bohaterowie zbiorowej wyobraźni. To wychowani w niewoli orędownicy pracy organicznej, wykorzystujący swoje doświadczenia z okresu aktywności konspiracyjnej oraz jawnej w granicach prawa narzuconego im przez państwa zaborcze. W tej grupie znaleźli się zarówno liderzy przedsięwzięć społecznych, organizacji gospodarczych, jak i politycy uczestniczący w budowie prawnych założeń i instytucjonalnych fundamentów suwerennego państwa. W tych kategoriach należy zatem postrzegać również działalność Błażeja Stolarskiego w latach $1914-1922^{1}$.

Jak można w najkrótszy sposób scharakteryzować bohatera artykułu? Była to postać wielowymiarowa, odbiegająca od standardów typowego rolnika i działacza ludowego. To przede wszystkim człowiek poszukujący, który dzięki pasji samokształcenia, bogatej wiedzy zawodowej, chłopskiemu uporowi był w stanie walczyć nie tylko z przeciwnościami losu, ale i organizować życie lokalnej społeczności oraz uczestniczyć w budowie zrębów niepodległej Rzeczypospolitej. Dokonania Stolarskiego z okresu I wojny światowej i kadencji Sejmu Ustawodawczego

I Prezentowany artykuł stanowi rozbudowaną wersję referatu wygłoszonego podczas konferencji Ruch ludowy i polska wieś wobec Niepodlegtości (Supraśl - Nidzica, 19-2I IX 2018 r.), zorganizowanej przez białostocki Oddział IPN. 
warto przedstawić zatem na trzech uzupełniających się płaszczyznach aktywności: politycznej, w organizacjach społecznych i gospodarczych oraz na niwie samorządowej.

\section{Budowa wizerunku lidera}

Błażej Stolarski urodził się 2 II I 880 r. w Ciebłowicach jako syn Wojciecha i Małgorzaty z domu Piechna. Nie uczęszczał do szkoły. Czytać i pisać uczył się z elementarza Konrada Prószyńskiego (Kazimierza Promyka), a w nauce wspierali go najpierw robotnicy $\mathrm{z}$ Inowłodza zatrudnieni w pobliskich lasach, a następnie pan Anoży, pochodzący z Kujaw były powstaniec styczniowy ${ }^{2}$. W efekcie podjętego samokształcenia Stolarski już jako osiemnastolatek pisywał artykuły do czasopism, a za sprawą swojej postawy i poglądów zyskiwał coraz większy autorytet na wsi3. Pierwszym przedsięwzięciem, dzięki któremu zacząl być postrzegany jako przywódca lokalnego środowiska, była organizacja zbiorowego przesiedlenia z terenów piaszczystych i nękanych przez dzikie zwierzęta lasów spalskich w okolice posiadające lepsze gleby, na miejsce rozparcelowanego majątku Wykno. Wywołany tym wydarzeniem wzrost prestiżu Stolarskiego zaowocował objęciem przez niego funkcji sołtysa nowej wsi Sługocice ${ }^{4}$. Nowe pole aktywności dla młodego sołtysa otworzyły stowarzyszenia rolnicze (kółka rolnicze i kasy pożyczkowo-oszczędnościowe) oraz spółdzielnie produkcyjno-usługowe. To między innymi dzięki zaangażowaniu w ich tworzenie i działalność, w ciągu dziesięciu lat od przeniesienia wsi, Błażej Stolarski zyskał opinię przodującego rolnika w rodzinnej miejscowości i okolicy, laureata pokazów i konkursów, a jego posiadłość stała się ośrodkiem postępu rolniczegos.

Następny etap w rozwoju kariery i osobowości prężnego rolnika i lokalnego aktywisty wiódł do polityki. Sołtys Sługocic związał się z ruchem narodowym, do którego doprowadziła go działalność oświatowa i w kółkach rolniczych. W I905 r. wziął udział w patriotycznej demonstracji pod przewodnictwem ks. Alfonsa Trepkowskiego i zgromadzeniu

2 P. Perzyna, Btażej Stolarski I880-1939. Biografia spotecznika, dziatacza gospodarczego i polityka, Łódź-Warszawa 2017, s. 15, I8; S. Giza, Btażej Stolarski 1880-1939, [w:] Przywódcy ruchu ludowego. Szkice biograficzne, red. A. Więzikowa, Warszawa 1968, s. 313.

3 B. Stolarski, Dziatacz spoteczny na wsi, „Wyzwolenie” 1936, nr 30, s. 3.

4 Tamże; P. Perzyna, Btażej Stolarski I880-1939..., s. 30-31; J. Socha, Btażej Stolarski (1880-1939). Szkic do biografii, [w:] $Z$ dziejów ruchu ludowego w regionie tódzkim, red. W. Piątkowski, Warszawa 1992, s. 123.

5 P. Perzyna, Btażej Stolarski - sylwetka dziatacza wszechstronnego, „Roczniki Dziejów Ruchu Ludowego" 2018, nr 37, s. 799-800. 
zorganizowanym w Będkowie pod hasłem walki o wprowadzenie języka polskiego w szkołach i urzędach. W kolejnych latach uczestniczył w innych lokalnych zebraniach publicznych, w trakcie których przemawiał „w imię Polski i polskości”. W efekcie tej wiecowej aktywności już przed I wojną światową Stolarski włączył się w prowadzenie konspiracyjnej działalności niepodległościowej, polegającej m.in. na organizowaniu wyjazdów na kursy wojskowe do Warszawy miejscowej młodzieży, która w przyszłości miała zasilić oddziały Legionów Polskich ${ }^{6}$.

\section{Działalność w okresie I wojny światowej}

W I9I2 r. Błażej Stolarski został jednym ze współzałożycieli Narodowego Związku Chłopskiego (NZCh), postulującego odzyskanie niepodległości poprzez walkę zbrojną z Rosją przy wydatnym udziale chłopstwa. Warto przypomnieć, że NZCh zakładał istnienie w wolnym państwie reprezentacji chłopów w sejmie oraz wywieranie za ich pośrednictwem wpływu na rządy, ale ważne dla chłopów kwestie społeczne odkładał na nieokreśloną przyszłość ${ }^{7}$. Podobnie jak wielu innych działaczy NzCh Stolarski szybko włączył się w działalność niepodległościową. W okresie I wojny światowej został członkiem Polskiej Organizacji Wojskowej ${ }^{8}$ i w jej ramach podjął współpracę z ośrodkiem w Retkini, gdzie spotykali się „emisariusze” prowadzący na publicznych wiecach i podczas zebrań konspiracyjnych, m.in. w: Brzezinach, Łasku, Szadku, Zduńskiej Woli, Sieradzu, Aleksandrowie, akcję uświadamiającą społeczeństwo w zakresie celów ruchu niepodległościowego9. To właśnie za te działania Prezydent RP przyznał Stolarskiemu zarządzeniem z 20 II 1932 r. Krzyż Niepodległości ${ }^{10}$.

6 S. Giza, dz.cyt., s. 320; W. Goliński, Kronika szkolna 7. klasowej Szkoty Powszechnej w Będkowie, gm. Będków, pow. brzeziński Okręgu Szkolnego Eódzkiego, s. 9 (rkps przechowywany w Zespole Szkolno-Gimnazjalnym w Będkowie); B. Stolarski, Dziatacz..., s. 3-4.

7 W gronie założycieli NzCh znaleźli się: Aleksander i Ludwika Zawadzccy, Antoni Piątkowski, Wacław Dunin, Jan Mazur, Franciszek Wielgut i Aleksander Bogusławski. Archiwum Zakładu Historii Ruchu Ludowego (dalej: AZHRL), sygn. O-55, T. Frankowski, Próby opanowania ruchu chtopskiego przez Narodową Demokrację w Królestwie Polskim. Narodowy Związek Chtopski, Warszawa 1961, s. 55-56; J. Konefał, Aleksander Zawadzki - „Ojciec Prokop” (1859-1926), „Roczniki Dziejów Ruchu Ludowego" 1986 , nr 26, s. 82-83.

8 B. Stolarski, Orka, „Wyzwolenie” I935, nr 26, s. 2-3. Zob. też: J. Holzer, J. Molenda, Polska w pierwszej wojnie światowej, Warszawa 1967 , s. 172.

9 W gronie „emisariuszy” można wymienić: Jerzego Ostoję-Neugebauera, Tadeusza Hołówkę, Błażeja Stolarskiego, Tomasza Nocznickiego, Mieczysława Jeżewskiego, Juliusza Poniatowskiego i dr. Stefana Kopcińskiego. J. Klimek, Park Amunicyjny Legionów Polskich w Eodzi, „Niepodległość” 1934, t. 9, s. 393.

Io Monitor Polski 1932, nr I67, poz. 198, Zarządzenie o nadaniu Krzyża Niepodległości z Mieczami, Krzyża Niepodległości i Medalu Niepodległości. 
W połowie sierpnia I9ı4 r. NZCh wszedł w skład Zjednoczenia Organizacji Niepodległościowych, a trzy miesiące później, po rozpadzie tegoż, znalazł się w Konfederacji Polskiej (KP), dla której zawiesił swoją działalnośćn ${ }^{\prime \prime}$ Stolarski nie odegrał w tym bloku politycznym znaczącej roli, na co zapewne miał wpływ brak wykształcenia i obycia politycznego. Trzeba bowiem pamiętać, że pracami KP kierowali tacy doświadczeni działacze, jak: Aleksander Zawadzki, Wacław Dunin, Antoni Piątkowski z NZCh, Władysław Malangiewicz, Adam Radlicki i Jan Jankowski z Narodowego Związku Robotniczego, Karol Popiel ze Związku Inteligencji Niepodległościowej ${ }^{\mathrm{I2}}$. Pozycja lokalnego aktywisty nie przeszkodziła jednak gospodarzowi ze Sługocic uczestniczyć, na zaproszenie szefa Departamentu Wojskowego Władysława Sikorskiego, w zjeździe reprezentantów Naczelnego Komitetu Narodowego (NKN) z przedstawicielami Królestwa Polskiego, który odbył się 3 VI I9I5 r. w Piotrkowie. Zjazd zakończył się przyjęciem deklaracji potwierdzającej prawo Królestwa Polskiego do samodzielności i niepodległości oraz dążenie do połączenia w przyszłości Królestwa i Galicji ${ }^{13}$.

$\mathrm{Na}$ gruncie poparcia dla idei walki przeciwko Rosji i tworzenia w tym celu Legionów i Polskiej Organizacji Wojskowej doszło, na początku sierpnia I9I5 r., do zjednoczenia Konfederacji Polskiej i Unii Stronnictw Niepodległościowych w Komitecie Naczelnym Zjednoczonych Stronnictw Niepodległościowych ${ }^{14}$. Warto jednak przypomnieć, że w tym samym czasie w NZCh narastał antagonizm między grupą opowiadającą się za zerwaniem łączności organizacyjnej z KP z Zawadzkim na czele, a zwolennikami samodzielnej walki o pełną niepodległość, której zalążkiem miało być Królestwo Polskie. Punkt szczytowy sporu nastąpił 6 X I9Is r., kiedy to z NZCh wyodrębnił się Związek Ludu Polskiego (ZLP), w którego Zarządzie Głównym znalazł się m.in. Błażej Stolarski ${ }^{15}$.

Z ramienia ZLP Stolarski wystąpił, I4 XI I9I5 r., na kolejnym zjeździe przedstawicieli Królestwa Polskiego w Piotrkowie, tym razem zorganizowanym z okazji przybycia prezesa NKN Władysława Leopolda Jaworskiego na lustrację biur i instytucji Departamentu Wojskowego. W trakcie obrad

II P. Perzyna, Btażej Stolarski. Droga do awansu cywilizacyjnego chtopa polskiego w latach Igoo-IgI8, "Acta Universitatis Lodziensis. Folia Historica” 1997 , t. 60, s. I4.

I2 A. Bogusławski, Ruch ludowy w czasie wojny IgI4-IgI8 w Królestwie Polskim wświetle wspomnień, „Roczniki Dziejów Ruchu Ludowego” 1959, nr I, s. 267.

13 Archiwum Państwowe w Krakowie, Naczelny Komitet Narodowy (dalej: APKr, NKN), t. I03, k. 62, Deklaracja zjazdu piotrkowskiego z 3 VI 1916 r.; tamże, k. 75, Lista obecności; tamże, k. 150, Wzór zaproszenia podpisany przez Władysława Sikorskiego.

I 4 P. Perzyna, Btażej Stolarski I880-1939..., s. 68-69.

I5 Archiwum Państwowe w Łodzi, Zbiór druków i pism ulotnych, t. 168, k. I, „Polak”, nr I, lipiec 1916 r.; AZHRL, sygn. O-55, T. Frankowski, Próby opanowania..., s. 87. 
podpisał podjętą przez uczestników rezolucję podkreślającą potrzebę aktywizacji społeczeństwa i wykorzystania koniunktury międzynarodowej do odzyskania w wyniku trwającej wojny suwerennego państwa, a także postrzegającą Legiony Polskie i działalność NKN za bezpośredni wyraz polskiej polityki państwowej ${ }^{16}$.

Trzy tygodnie później, w dniach 4-6 grudnia, odbył się w Warszawie zjazd zjednoczeniowy Stronnictwa Ludowego, Związku Chłopskiego i Związku Ludu Polskiego. Stolarski nie awansował co prawda do władz Polskiego Stronnictwa Ludowego, ale już I8 XII I9I5 r. został reprezentantem Polskiego Stronnictwa Ludowego i Łodzi w składzie Centralnego Komitetu Narodowego (CKN), który stał się kolejną federacją zrzeszającą stronnictwa niepodległościowe Królestwa Polskiego ${ }^{17}$. Z inicjatywy warszawskich działaczy CKN w lipcu 1916 r. powołano z kolei 19-osobową Radę Narodową miasta Łodzi. Obok tak znanych działaczy niepodległościowych, jak m.in. Ludwik Waszkiewicz, Bolesław Fichna, Stefan Kopciński, Jerzy Ostoja-Neugebauer i Aleksy Rżewski, znalazł się w niej, jako przedstawiciel PSL, Błażej Stolarski. Rada nie podjęła szerszej działalności politycznej i przetrwała do lutego $1917 \mathrm{r}$. Jedynym widocznym efektem jej istnienia było przeprowadzenie w październiku 1916 r. dużej kampanii przeciwko przymusowemu wysyłaniu robotników do pracy w Niemczech ${ }^{18}$.

Dnia 5 XI 1916 r. w imieniu cesarza Niemiec Wilhelma II i cesarza Austro-Węgier Franciszka Józefa stojący na czele stref okupacyjnych generałowie-gubernatorzy ogłosili odezwę, znaną jako akt 5 listopada, zakładającą utworzenie z okupowanych ziem zaboru rosyjskiego samodzielnego Królestwa Polskiego w bliżej nieokreślonych granicach będącego dziedziczną monarchią konstytucyjną. Miesiąc później generał-gubernator warszawski Hans Beseler podpisał rozporządzenie w sprawie powołania Tymczasowej Rady Stanu (TRS), która miała spełniać rolę organu doradczego, przygotowującego podstawy organizacyjne dla instytucji przyszłego państwa polskiego ${ }^{19}$. TRS rozpoczęła działalność I4 I 1917 r., a Stolarski uczestniczył we wszystkich dwudziestu posiedzeniach plenarnych pomiędzy 17 stycznia a 2 lipca. Został

I6 APKr, NKN, t. I03, k. 97, Zjazd w Piotrkowie I4 XI I9I5 r. z udziałem prezesa NKN; tamże, k. Iı--III, Rezolucja uczestników Zjazdu; P. Perzyna, Btażej Stolarski I880-1939..., s. 70.

17 Stolarski pozostał w CKN do maja 1917 r. J. Molenda, Polskie Stronnictwo Ludowe w Królestwie Polskim IgIs-19I8, Warszawa 1965, s. 31, 76; J. Pająk, O rząd i armię. Centralny Komitet Narodowy (I9I5-1917), Kielce 2003, s. 246.

I8 J. Pająk, dz.cyt., s. 303-305; A. Barszczewska-Krupa, P. Samuś, Życiepolityczno-spoteczne, [w:] Łódź. Dzieje miasta, t. I, red. B. Baranowski i J. Fijałek, Warszawa-Łódź 1988, s. 464; P. Perzyna, Btazej Stolarski I880-1939..., s. 72.

I9 J. Pajewski, Odbudowa państwa polskiego I9I4-I9I8, Warszawa I985, s. I25, I35-I36; P.K. Marszałek, Najwyższe wtadze wojskowe w systemie ustrojowym II Rzeczypospolitej, Wrocław 20II, s. 73. 
członkiem i brał udział w pracach rad departamentów: Spraw Wewnętrznych, Pracy oraz Gospodarstwa Społecznego. Z uwagi na wagę sprawy, jaką było zorganizowanie wojska oraz określenie prawno-politycznego statusu Legionów, zgodnie z sugestią Józefa Piłsudskiego, ro lutego wybrano go również wraz z czterema innymi radcami w skład Komisji Wojskowej ${ }^{20}$.

Powołanie w skład TRs było dla kariery politycznej Błażeja Stolarskiego momentem przełomowym. Zaczął być postrzegany już nie tylko jako polityk lokalnego, ale i ogólnopolskiego formatu, a pozytywna ocena jego zaangażowania w działalność Rady szybko zaowocowała awansem w hierarchii partyjnej. W lutym I9I7 r. podczas walnego zjazdu PSL, w którym uczestniczył Piłsudski, Stolarski został członkiem Zarządu Głównego PSL, a trzy miesiące później objął, po Tomaszu Nocznickim, stanowisko prezesa stronnictwa. Pełnił je przez pięć kolejnych, przełomowych dla budowy zrębów niepodległej Polski lat, a jednocześnie, co warto podkreślić, kierował pracami okręgu brzezińsko-tomaszowskiego PSL, którego centrum mieściło się w Stugocicach ${ }^{21}$.

W kontekście rozwoju kariery politycznej warto zwrócić uwagę na trzy kolejne aspekty działalności gospodarza ze Sługocic w okresie I wojny światowej. Pierwszy to aktywność na forum samorządu. W połowie 1916 r. Stolarski został mianowany członkiem sejmiku powiatowego w Łodzi i z jego ramienia uczestniczył w latach 1916-I9I8 w zjazdach sejmików w Warszawie. Rok później objął funkcję przewodniczącego rady gminy w Będkowie ${ }^{22}$. Warto w tym miejscu podkreślić, że zgodnie z poglądami prezesa PSL „Wyzwolenie” wyłożonymi w artykułach z września I9I8 r., samorząd miał w przyszłości stanowić jeden $\mathrm{z}$ ważnych elementów w budowie suwerennego państwa polskiego. W jego koncepcji większość spraw wewnętrznych w państwie powinno być rozstrzyganych właśnie w gminach wiejskich i miejskich, stanowiących ośrodki życia społecznego respektujące zasady równości i sprawiedliwości. Wiele miało zależeć od zgodnej współpracy rady gminy będącej organem doradczym oraz zarządów gmin isamego wójta ponoszącego odpowiedzialność z tytułu: utrzymania w odpowiednim stanie dróg lokalnych, zapewnienia

20 P. Perzyna, Btażej Stolarski I880-1939..., s. 76-77, 80.

2I J. Molenda, dz. cyt., s. 62, 166; J. Socha, Btażej Stolarski..., s. 126.

22 A. Jaros, Sejmiki powiatowe w okupacji niemieckiej, „Wyzwolenie” 1918, nr I2, s. II5; P. Perzyna, Btażej Stolarski I880-I939..., s. 63, 66. Sejmiki powiatowe na terenach okupowanych przez Niemców powołano w $1916 \mathrm{r}$. na podstawie ordynacji powiatowej z 22 stycznia. Miały się one składać z I2-24 członków i realizować zadania w zakresie opieki nad biednymi i wspierania rodzin rezerwistów, utrzymania istniejących dróg i budowy nowych, ochrony zdrowia i sanitarnej, wspierania rozwoju rolnictwa oraz przemysłu i handlu. Wybory delegatów planowano odbywać co sześć lat, ale w $1916 \mathrm{r}$. nie zostały one przeprowadzone. Mianowania członków sejmików dokonał naczelnik Zarządu Cywilnego Generalnego Gubernatorstwa Warszawskiego. Tamże, s. 66. 
bezpieczeństwa mieszkańców, zarządzania nieruchomościami, wywierania wpływu na podniesienie wydajności w rolnictwie i rozwój stowarzyszeńn ${ }^{23}$.

Drugim obszarem jego zainteresowań były kwestie związane z szerzeniem oświaty w społeczeństwie, szczególnie istotne w momencie odbudowywania tożsamości narodowej i instytucji niepodległego państwa. Gospodarz ze Sługocic słusznie bowiem zakładał, że dla przyszłej Polski niezbędne będzie podniesienie poziomu umysłowego społeczności wiejskiej, celowo pozbawianej możliwości kształcenia przez zaborców. Światły i podnoszący swoje kwalifikacje chłop stanowił też nadzieję na odbudowę krajowej gospodarki zdewastowanej w wyniku działań wojennych.

Błażej Stolarski, sam będąc samoukiem, stał się fundatorem szkoły elementarnej zarejestrowanej jako ochronka w Sługocicach, która rozpoczęła działalność Is XI I9I4 r. Przeznaczone na ten cel środki pochodziły z nagrody pieniężnej w wysokości 300 rubli przyznanej mu przez Główny Zarząd Organizacji Gospodarstw i Rolnictwa w Petersburgu z okazji trzechsetlecia panowania dynastii Romanowów, I9 II 1914 r., za prowadzenie wzorowego gospodarstwa ${ }^{24}$. Przez cztery lata Stolarski był głównym darczyńcą szkoły, dodatkowo bez wsparcia będkowskiej gminy w I9I8 r. na potrzeby szkoły rozbudował swój dom. Zapewne w uznaniu jego zasług w sferze działań społeczno-oświatowych w 1916 r. powierzono mu funkcję przewodniczącego Miejscowej Rady Opiekuńczej w Będkowie. Jej zadaniem miało być udzielanie pomocy materialnej ludności poszkodowanej w trakcie wojny, prowadzenie schronisk, przytułków i ochronek oraz rejestracja strat wojennych. Podstawę finansowania przedsięwzięć rady stanowiły subsydia otrzymywane z Rady Głównej Opiekuńczej za pośrednictwem lódzkiej Rady Opiekuńczej, a także ofiary społeczeństwa w postaci składek oraz wpływów z kwest i zbiórek publicznych. Z uwagi na konflikty personalne będkowska MRO przetrwała jedynie dziewięć miesięcy. Jako szef rady Stolarski, poza wspieraniem działalności charytatywnej, zwracał uwagę na niską efektywność oświaty na wsi wynikającą z krótkich, kilkumiesięcznych okresów nauki, nieuczęszczanie części dzieci na zajęcia lekcyjne i zbyt duże grupy uczniów przypadające na jednego nauczyciela. W związku z powyższym złożył petycję do Rady Szkolnej Okręgu Łódzkiego w sprawie organizacji obowiązkowego szkolnictwa elementarnego i zaprowadzenia powszechnego, równego, opartego na wysokości dochodów opodatkowania szkolnego ${ }^{25}$.

23 B. Stolarski, Kilka uwago naszej gminie, „Wyzwolenie” 1918, nr 35, s. 314; tenże, Jakie winno być wspótdziatanie wójta i pisarza, „Wyzwolenie” 1918, nr 57, s. 330.

24 Tenże, Stugocice. Obraz życia i pracy jednej wioski, Warszawa 1925, s. 102, 150-151.

25 P. Perzyna, Btażej Stolarski $1880-1939 \ldots$, s. 55-56. 
W I9I7 r. gospodarz ze Sługocic został współzałożycielem Towarzystwa „Uczelnia Polska” im. Tadeusza Kościuszki w Będkowie oraz wspólinicjatorem powstania progimnazjum w Będkowie. Szkoła przetrwała jedynie dwa lata - do lipca 1920 r. Przez cały okres jej istnienia funkcję prezesa zarządu rady szkolnej pełnił Stolarski. Przyczyną likwidacji placówki były przede wszystkim zbyt wysokie koszty utrzymania, chociaż zaangażowanie finansowe Błażeja Stolarskiego w powyższe przedsięwzięcie należy ocenić jako znaczące. Tylko w latach 1917-1919 wplacił on bowiem udziały w wysokości $3000 \mathrm{mkp}$ oraz pożyczył Towarzystwu $1828 \mathrm{mkp}^{26}$.

Kolejną formą krzewienia wiedzy i podnoszenia kultury na terenie powiatu brzezińskiego było zaangażowanie Stolarskiego w tworzenie na wsi bibliotek i czytelni w ramach Towarzystwa Oświatowego „Wiedza” (powstałego w marcu 1916), a następnie Polskiej Macierzy Szkolnej w Brzezinach. Należy podkreślić, że wspomniane towarzystwo oprócz podnoszenia poziomu czytelnictwa wśród mieszkańców Brzezin i powiatu brzezińskiego, stawiało sobie za cel organizowanie kursów dla analfabetów, kursów ogólnokształcących i wieczorowych, odczytów i pogadanek, wieczorów literackich, przedstawień teatralnych, koncertów, zabaw i konkursów ${ }^{27}$.

Trzeci kierunek aktywności Stolarskiego stanowiły organizacje społeczno-gospodarcze. W I91 6 r. został on dokooptowany do grona członków Zarządu Wydziału Kółek Rolniczych Centralnego Towarzystwa Rolniczego (CTR), a już rok później objął nieformalne przywództwo w grupie działaczy Wydziału domagających się reform wewnętrznych. Starcie przeciwników i zwolenników wniosku gospodarza ze Sługocic w sprawie utworzenia samodzielnej organizacji kółek rolniczych zostało rozstrzygnięte na zjeździe przedstawicieli kółek w styczniu I9I8 r. Wydział przybrał odtąd nazwę Związek Kółek Rolniczych (ZKR) oraz uzyskał większą samodzielność i wpływ na pracę CTR. Stolarski został wiceprezesem ZKR, przekształconego w marcu $1920 \mathrm{r}$. w samodzielny Centralny Związek Kółek Rolniczych, i funkcję tę pełnił do $1928 \mathrm{r}^{28}$

Omawiając działalność społeczną i polityczną Stolarskiego w okresie I wojny światowej warto pamiętać, że nie rozwijała się ona w warunkach wolności narodowej oraz przestrzegania przez państwa okupacyjne swobód obywatelskich. Ponosił więc konsekwencje swoich wyborów. Po latach wspominał,

\footnotetext{
26 B. Stolarski, Stugocice..., s. I57; F. Stolarski, Towarzystwo „Uczelnia Polska” im. Kościuszki w Będkowie, „Roczniki Dziejów Ruchu Ludowego” 1972, nr I 4, s. 337-339.

27 P. Perzyna, Btażej Stolarski 1880-1939..., s. 57-58.

28 Archiwum Akt Nowych, Centralne Towarzystwo Rolnicze, t. 137, k. 252-253, Pismo Stefana Biedrzyckiego do Prezydium CTR z 5 XII 1916 r. wraz z listą członków Zarządu w KR; B. Stolarski, Związek drobnych rolników, „Przewodnik Kółek i Spółek Rolniczych w Królestwie Polskim”, I5 II 19I7, nr 7, s. 54. P. Perzyna, Btażej Stolarski-sylwetka..., s. 80I.
} 
że w I9I4 r. Rosjanie zagrozili mu wysiedleniem w inne okolice, ale nie zdążyli już tego dokonać. Represje Niemców okazały się bardziej dotkliwe i polegały na prowadzonym metodycznie rabunku jego gospodarstwa, które stanowiło jedyne źródło utrzymania dla całej rodziny. Oprócz rekwizycji zbóż najdotkliwszą karą stało się zniszczenie jego przedsięwzięcia hodowlanego, a zwłaszcza obory, którą Stolarski doprowadził przed wojną do takiego stanu, że można ją było traktować jako zarodową dla bydła rasy czerwonejj"

Ostatnie dni okupacji niemiecko-austriackiej Błażej Stolarski spędził w Lublinie, gdzie stronnictwa skupione w Komisji Porozumiewawczej Stronnictw Demokratycznych utworzyły w nocy z 6 na 7 listopada Tymczasowy Rząd Ludowy Republiki Polskiej z Ignacym Daszyńskim na czele. Prezes PSL „Wyzwolenie” został w nim ministrem bez teki oraz sygnatariuszem jego odezwy programowej³ ${ }^{30}$ Pięć dni później gabinet złożył dymisję na ręce Józefa Piłsudskiego. Po powrocie z Lublina i rozbrojeniu przez oddział POW w nocy z in na I2 listopada stacjonujących w Będkowie Niemców, Stolarski objął obowiązki wójta gminy. Zakończenie jego misji na tym stanowisku nastąpiło prawdopodobnie 7 I I9I9 r. $^{31}$

\section{W rządzie i Sejmie Ustawodawczym Rzeczypospolitej Polskiej}

Dnia I8 XI I9I8 r. powstał rząd Jędrzeja Moraczewskiego. Tym razem prezes PSL „Wyzwolenie” nie wszedł w skład gabinetu. Przedstawiciele PSL „Piast” z Wincentym Witosem na czele, z uwagi na niewprowadzenie do gabinetu reprezentantów Poznańskiego, nie objęli z kolei swoich resortów i po miesiącu zostali odwołani z rządu przez własne stronnictwo. W efekcie zamieszania z ukształtowaniem koalicji wspierającej gabinet Moraczewskiego i obsadą w nim stanowisk, 29 grudnia funkcję ministra rolnictwa i dóbr państwowych objął Błażej Stolarski ${ }^{32}$. Maria Dąbrowska, podwładna gospodarza ze Sługocic, zapamiętała jego pierwsze spotkanie z pracownikami resortu w następujący sposób:

09.01.1919 r. Czwartek. Przedwczoraj nowy minister rolnictwa, chłop z Piotrkowskiego, Błażej Stolarski, zapoznał się z nami. Przedstawiono mu wszystkich urzędników. Miał przemowę, podczas której doznawałam wrażenia,

\footnotetext{
29 B. Stolarski, Dziatacz spoteczny na wsi, „Wyzwolenie” 1936, nr 31, s. 4; P. Perzyna, Btażej Stolarski I880-1939..., s. 94, 279.

30 S. Thugutt, Autobiografia, Warszawa 1984, s. IIo-III; A. Mieczkowski, Btażej Stolarski 1880-1939. Życie, dziatalność, poglady, Lublin 1998, s. 55; P. Perzyna, Btażej Stolarski I880-1939..., s. 93.

31 Tamże, s. I62-163.

32 J. Borkowski, Ludowcy w II Rzeczypospolitej, cz. I, Warszawa I987, s. $33,36$.
} 
że jestem na kazaniu w chłopskim kościele. Ale w tej ciężko wypowiedzianej mowie korzystnie się nam raczej pokazał, zaznaczając od razu swoje nieprzygotowanie i swoją chęć współpracy z całym Ministerstwem. Był to raczej dziwaczny widok tego chłopa z grubo ciosaną twarzą, w wysokich butach i spencerku, „z fontaziem” u koszuli - i tych naokoło, urzędniczych wprawdzie, ale często wyrafinowanych i subtelnych, a nawet mądrych twarzy różnych doktorów paru nieraz fakultetów, docentów i uczonych ${ }^{33}$.

Błażej Stolarski pełnił obowiązki szefa resortu rolnictwa co prawda jedynie przez osiemnaście dni, ale nie należy zapominać, że w tym czasie zdążył mianować pewną liczbę urzędników w ministerstwie oraz w głównej i okręgowych komisjach ziemskich, a także przyczynić się do wprowadzenia kilku ważnych aktów prawnych odnoszących się do kwestii majątku narodowego, rolnictwa i leśnictwa. Warto zatem przyjrzeć się jego ministerialnym dokonaniom. Z inspiracji resortu rolnictwa, dzień po nominacji Stolarskiego, rząd Moraczewskiego wydał postanowienie o ochronie i użytkowaniu lasów. Na jego podstawie wszystkie lasy miały znaleźć się pod obowiązkowym nadzorem i kontrolą urzędów ochrony lasów, a eksport drewna poza granice państwa mógł nastąpić tylko po uzyskaniu zezwolenia ministra rolnictwa i dóbr państwowych ${ }^{34}$. Uzupełnieniem prawnego zabezpieczenia lasów, zwłaszcza w zakresie przeciwdziałania dewastacji oraz promowania ich pielęgnacji i odnawiania, stał się dekret dotyczący organizacji urzędów ochrony lasów podpisany m.in. przez ministra Stolarskiego w dniu dymisji gabinetu Moraczewskiego. W skład wspomnianych urzędów, podlegających bezpośrednio ministrowi rolnictwa i dóbr państwowych, miały wchodzić: główny inspektor ochrony lasów, inspektorzy okręgowi, komisarze i podkomisarze oraz urzędnicy pomocniczy i gajowi. Dekret zobowiązywał jednocześnie urzędy ochrony lasów do prowadzenia statystyki leśnej, sporządzania planów gospodarczych i kosztorysów, popierania produkcji nasion i sadzonek oraz zachęcania rolników do zakładania szkółek leśnych ${ }^{35}$.

W piątym dniu urzędowania, 2 I I9I9 r., minister Błażej Stolarski wydał dwa rozporządzenia w sprawie ustanowienia zarządu państwowego nad majątkiem pozostawionym przez zaborców. Na ich mocy zarządcą dóbr „Ostrowy”, będących własnością wielkiego księcia Michała Romanowa, został Ludwik Kiwerski, a dóbr należących do ordynacji książąt

33 M. Dąbrowska, Dzienniki, t. I, Warszawa 1997, s. I32.

34 Dziennik Praw Państwa Polskiego (dalej: Dppp) 1919, nr 3, poz. 86, Postanowienie Rady Ministrów w przedmiocie ochrony i użytkowania lasów.

35 Tamże, 1919, nr 8, poz. 117, Dekret w przedmiocie organizacji urzędów ochrony lasów; P. Perzyna, Btażej Stolarski $1880-1939 \ldots$, s. 109. 
warszawskich hrabiów Paskiewiczów Erywańskich - Marcin Mierzejewski $^{36}$. Z kolei I stycznia, wraz z Tymczasowym Naczelnikiem Państwa i premierem, podpisał dekret dotyczący umów zawartych przez byłe władze okupacyjne w zakresie majątku państwowego. Unieważniał on wszelkie zobowiązania byłych władz okupacyjnych oraz działających w ich imieniu instytucji i osób dotyczące majątku państwowego, nie wyłączając dóbr donacyjnych, a także wszystkie porozumienia w zakresie wyrębu i eksploatacji lasów, sprzedaży materiału drzewnego oraz odnoszące się do środków transportu, zakładów przetwórczych, maszyn i inwentarza stanowiącego własność państwową ${ }^{37}$. Warto także pamiętać, że to właśnie w okresie pełnienia przez Stolarskiego ministerialnego urzędu przygotowano ogólny zarys projektu uchwały o reformie rolnej oraz przeniesiono siedzibę Okręgowej Komisji Ziemskiej z Łodzi do Piotrkowa ${ }^{38}$.

Dziesięć dni po dymisji rządu Moraczewskiego odbyły się wybory do Sejmu Ustawodawczego. W ich wyniku Błażej Stolarski otrzymał mandat z okręgu łódzkiego, obejmującego powiaty brzeziński, łaski i łódzki, a następnie posłowie PSL „Wyzwolenie” wybrali go prezesem 57-osobowego klubu poselskiego. W ten sposób gospodarz ze Sługocic, podobnie jak Witos W PSL „Piast”, skupił w swoim ręku najbardziej kluczowe stanowiska w stronnictwie. Jak miała pokazać przyszłość, nie okazał się on jednak tej miary indywidualnością, by móc odegrać porównywalną do swojego konkurenta politycznego rolę w stronnictwie i polityce ogólnopaństwowej. Nie miał charyzmy wodza, ale z drugiej strony trudno nie zauważyć jego zdolności mediacyjnych i biegłości w szukaniu kompromisu. Skromność, pozytywistyczny dorobek życiowy i działalność niepodległościowa Stolarskiego w okresie wojny łagodziły w pewien sposób ostrość sporów i napięć wewnątrz klubu i stronnictwa ${ }^{39}$.

O tym, jak Stolarski rozumiał służbę Polsce u progu budowy instytucji demokratycznego państwa, najlepiej świadczy jego artykuł zatytułowany „Po wyborach”, opublikowany 2 II I9I9 r. na łamach „Wyzwolenia”. Apelował w nim do społeczeństwa o podjęcie intensywnej pracy na rzecz ojczyzny,

36 Monitor Polski 1919, nr 5, s. I, Ustanowienie zarządu państwowego nad dobrami „Ostrowy” W. Ks. M. Romanowa, położonemi w powiecie Częstochowskim.; tamże, Ustanowienie zarządu państwowego nad dobrami, należącemi do Ordynacji (Majoratu) Książąt Warszawskich Hrabiów Paskiewiczów Erywańskich.

37 DPPP, 1919, nr 5, poz. 99, Dekret w przedmiocie umów, zawartych przez b. władze okupacyjne co do majątku publicznego; P. Perzyna, Btażej Stolarski I880-1939..., s. IIo.

38 S. Giza, dz. cyt., s. 316; P. Perzyna, Btażej Stolarski I880-1939..., s. I09.

39 Tamże, s. III-II3. T. Kisielewski, (Heroizm i kompromis. Portret zbiorowy dziataczy ludowych, cz. 2, Warszawa 1979, s. 192, 205) uważał, że Stolarski był figurą na szachownicy gry politycznej i działaczem na miarę powiatu, a nie państwa. 
ponoszenie współodpowiedzialności za losy i odbudowę kraju, wyrażające się m.in. poprzez regulowanie zobowiązań podatkowych oraz udzielanie wsparcia organom państwowym utrzymującym ład i porządek w państwie. „Budowę państwa - pisał - trzeba rozpocząć od każdej polskiej rodziny, chaty, zagrody, domu mieszczańskiego, polskich dróg, podniesienia kultury rolnej, prowadzenia dobrze gospodarki leśnej, ogrodnictwa, hodowli itp., od dźwigania przemysłu i handlu" ${ }^{\circ}$.

W pracy poselskiej Błażej Stolarski, jako wiceprzewodniczący Komisji Rolnej, skupił się na problemie reformy rolnej, obok konstytucji i kształtowania granic państwa jednego z najważniejszych zagadnień stanowiących przedmiot obrad Sejmu Ustawodawczego. Jego poglądy na kwestię zmiany struktury własności w rolnictwie i rolę chłopów w państwie, prezentowane w debacie sejmowej oraz broszurze Chtop a reformy rolne, ukształtowaty tradycyjne uprzedzenia oraz oczekiwania i interesy środowiska, w którym żył i pracował, oraz doświadczenia jego przodków. Warto jednak zauważyć, że Stolarski przez cały okres batalii o wprowadzenie zmian struktury własności ziemi podkreślał, że nie można ich dokonać na sposób „bolszewicki”, niszcząc własność prywatną, ale poprzez przygotowanie dobrych uregulowań prawnych ${ }^{4 r}$.

Dwadzieścia lat po odzyskaniu niepodległości Feliks Honowski pisał o radykalizacji PSL, która nastąpiła w I9I8 r. pod wpływem ideologii socjalistycznej oraz podżeganiu włościan do radykalnych wystąpień przez Stanisława Thugutta, wspieranego rzekomo przez Tomasza Nocznickiego i Błażeja Stolarskiego ${ }^{42}$. Trudno byłoby jednak w pierwszych latach II Rzeczypospolitej znaleźć tekst Stolarskiego wzywający do wprowadzenia własności społecznej, czy też domagający się parcelacji ziemi bez odszkodowania. Na poparcie tej tezy warto przytoczyć wydarzenia ze zjazdu ludowego zorganizowanego I4-Is lutego w Wilnie przez Polski Związek Ludowy „Odrodzenie”. Przybyło na niego około sześć tysięcy osób, a wśród zaproszonych gości znaleźli się reprezentanci PSL „Wyzwolenie”: Irena Kosmowska, Józef Kotnis i Błażej Stolarski. To właśnie prezesowi partii przypadło w udziale przedstawienie uchwaty sejmowej o zasadach reformy rolnej z Io VII $1919 \mathrm{r}$. Wyjaśnienia w tej kwestii nie przekonały jednak uczestników zjazdu, którzy wypowiedzieli się za realizacją radykalnej wersji reformy rolnej, polegającej

40 B. Stolarski, Po wyborach, „Wyzwolenie” 1919, nr 5, s. 58-59.

4I Tenże, Chtop a reformy rolne, Warszawa 1919, s. 4-I4; P. Perzyna, Btażej Stolarski I880-I939..., s. 150,176 .

42 Zob. F. Honowski, Parlament i rząd w Polsce niepodlegtej. Część prawno-polityczna. Stowo wstępne, rok IgI8, Warszawa 1938, s. 178,351,356. Zob. także: tenże, Prawno-polityczne dążenia wsi polskiej na tle literatury ludowej: rok 1918-1938, Warszawa 1939, s. 44, I23. 
na wywłaszczeniu wielkiej własności ziemskiej bez wykupu. Ostatecznie, pod wpływem argumentów Stolarskiego delegaci PZL przyjęli uchwałę o odpłatnej parcelacji majątków, z zastrzeżeniem, że uzyskane w ten sposób środki finansowe zostaną przeznaczone nie na wypłatę odszkodowań dla właścicieli, lecz na rozwój gospodarki narodowej ${ }^{43}$. Jako poseł i lider jednego z ugrupowań parlamentarnych Stolarski poważnie potraktował zgłoszone podczas zjazdu skargi ludności litewskiej i białoruskiej głównie na polską administrację, zebrał je, a następnie 20 lutego przekazał Józefowi Piłsudskiemu. Jednocześnie prezes „Wyzwolenia” wręczył Naczelnikowi Państwa swój memoriał w sprawie ciężkiego położenia wspomnianej ludności opracowany na podstawie zebranych zażaleń oraz prosił o przyjęcie jej reprezentacji ${ }^{44}$.

Kolejną próbą politycznej odpowiedzialności gospodarza ze Sługocic były wydarzenia związane z przygotowaniem do odparcia ofensywy Armii Czerwonej i ratowaniem młodej, ledwo odzyskanej przez Polskę niepodległości. Dnia 9 Vi 1920 r. do dymisji podał się rząd Leopolda Skulskiego, a dwa tygodnie później jego następcą został Władysław Grabski. Z uwagi na groźbę inwazji wojsk Rosji Sowieckiej na etnicznie polskie ziemie, na wniosek nowego premiera Sejm Ustawodawczy powołał (I lipca) Radę Obrony Państwa (ROP) będącą najwyższym organem władzy państwowej, uprawnionym do decydowania o wszystkich sprawach dotyczących prowadzenia i zakończenia wojny ${ }^{45}$. Przedstawicielem PSL „Wyzwolenie” w gronie dziesięciu najwybitniejszych członków Sejmu wybranych do ROP został nie prezes klubu i stronnictwa, lecz lepiej przygotowany merytorycznie do pełnienia funkcji państwowych Jan Woźnicki. Podobna sytuacja miała miejsce 24 lipca, w momencie powołania koalicyjnego Rządu Obrony Narodowej na czele z Wincentym Witosem. „Wyzwolenie” reprezentował w nim, jako minister rolnictwa i dóbr państwowych, przyjaciel Stolarskiego i doświadczony polityk piłsudczykowski - Juliusz Poniatowski ${ }^{46}$.

43 K., „Odrodzenie” (ZWilna), „Wyzwolenie” 1920, nr 8, s. 91; P. Perzyna, Btażej Stolarski I880-1939..., s. I26.

44 Przekazanie skarg nastąpiło podczas wizyty Stolarskiego, Thugutta, Poniatowskiego, Tabora, Walerona i Franciszka Górnego złożonej Naczelnikowi Państwa. Zob. B. Stolarski, Do Naczelnika Państwa, „Wyzwolenie” 1920, nr 9, s. I08-109; A. Mieczkowski, dz. cyt., s. 80.

45 W skład Rop wchodzili: Naczelnik Państwa jako przewodniczący, marszałek sejmu, dziesięciu posłów wybranych przez sejm i reprezentujących zasiadające w nim partie, premier, trzech ministrów wyznaczonych przez Radę Ministrów, trzech przedstawicieli wojska wskazanych przez Naczelnego Wodza w zależności od sprawy będącej przedmiotem obrad. H. Zieliński, Historia Polski 1914-1939, Wrocław 1982, s. I10-111; K. Badziak, W oczekiwaniu na przetom. Na drodze od odrodzenia do zatamania państwa polskiego: listopad I9I8-czerwiec 1920, Łódź 2004, s. I54-I55.

46 P.K. Marszałek, Rada Obrony Państwa z Ig2o roku. Studium prawno historyczne, „Acta Universitatis Wratislaviensis", nr 2758, Prawo ccxcrv, Wrocław 1995, s. 72; A. Paczkowski, Wincenty Witos, premier rządu polskiego 24 VII 1920-I3 IX I92I, 28 V-I4 XII I923, IO V-I4 V I926, [w:] 
W dniu powołania gabinetu Witosa gospodarz ze Sługocic złożył w Sejmie w imieniu PSL „Wyzwolenie” oświadczenie programowe, w którym podkreślał, że najważniejszym celem działalności każdego stronnictwa powinna być niepodległość narodu. Wzywał społeczeństwo do skupienia się wokół Józefa Piłsudskiego oraz ofiarności na rzecz obrony państwa. Wyrażał poparcie dla rządu w nadziei, że wdroży on niezbędne reformy społeczne oraz doprowadzi do zakończenia wojny i zawarcia trwałego pokoju. Wsparł także ideę stworzenia przez Polskę, Ukrainę, Białoruś, Litwę, Łotwę, Estonię i Finlandię związku „republik ludowych” opartego „na zasadzie wzajemnego poszanowania wolności i równości”. Jego zdaniem taka federacja wolnych państw miała prowadzić do umocnienia niepodległości Polski i pokoju we wschodniej części Europy ${ }^{47}$.

Brak Stolarskiego w składzie Rady i Rządu Obrony Narodowej nie oznaczał jednak, że nie podejmował on działań zmierzających do aktywizacji społeczeństwa w obronie zagrożonej ojczyzny. Na terenie powiatu brzezińskiego został bowiem powołany w skład Obywatelskiego Komitetu Wykonawczego Obrony Państwa - jednego z tych, które tworzono spontanicznie w całym kraju, angażując w ich działalność, koncentrującą się na werbowaniu żołnierzy do armii ochotniczej oraz zbieraniu środków na jej wyekwipowanie, lokalne autorytety ${ }^{48}$.

Gospodarz ze Sługocic uczestniczył również, podobnie jak czynili to starosta brzeziński - Zygmunt Robakiewicz i inni lokalni politycy, w zebraniach gminnych zwoływanych w celu pobudzenia ofiarności mieszkańców powiatu brzezińskiego na rzecz zagrożonej ojczyzny poprzez wpłaty na fundusz pożyczki państwowej, ochotniczy zaciąg do wojska i zachęcanie do wstępowania do Polskiego Towarzystwa Czerwonego Krzyża. W ich trakcie apelował do społeczeństwa o zaangażowanie w powyższe inicjatywy ${ }^{49}$. Ten przekaz Stolarski wzmocnił dodatkowo is sierpnia przez opublikowanie na łamach „Wyzwolenia” odezwy wzywającej do obrony kraju przed najazdem Armii Czerwonej. „Dzicz moskiewska - pisał jako poseł na Sejm Ustawodawczy z okręgu łódzkiego - głodna i obdarta, zniszczy nasze mienie, zabierając majątki bezpłatnie [...] Bolszewicy nie uszanują naszych świętych tradycji i tego wszystkiego co najświętsze dla każdego Polaka”. Ewentualna klęska wojsk polskich - jak słusznie zauważył - umoż-

Prezydenci i premierzy Drugiej Rzeczypospolitej, red. A. Chojnowski, P. Wróbel, Wrocław 1992, s. 136.

47 Sprawozdaniestenograficznez I66 posiedzenia Sejmu Ustawodawczego (dalej: SSSU) z 24 VII Ig2o r., tamy i6-17.

48 P. Perzyna, Btażej Stolarski I880-1939..., s. I30.

49 B. Stolarski, Z pow. brzezińskiego, „Wyzwolenie” 1920, nr 31, s. 342. 
liwiłaby marsz Armii Czerwonej na zachód i narzucenie Europie i światu ustroju komunistycznego. Jako wypróbowany państwowiec odraczał konfrontację polityczną ze stronnictwami konserwatywnymi na następną kadencję sejmu, przypominając jednocześnie swoim wyborcom, że „dziś my jesteśmy panami i gospodarzami w naszym domu, a właściwie w niedługim czasie będziemy"so.

Po zwycięskiej dla strony polskiej bitwie warszawskiej, a następnie trwającej od 20 do 26 września bitwie nad Niemnem i wyparciu bolszewików z Galicji Wschodniej, I2 października doszło do podpisania preliminaryjnego traktatu pokojowego i umowy o rozejmie, które sześć dni później doprowadziły do zawieszenia broni ${ }^{\text {s. }}$. Zabierając głos $\mathrm{w}$ imieniu PSL „Wyzwolenie” (22 października) w dyskusji nad ustawą o ratyfikacji umowy o rozejmie i preliminariach pokojowych, Stolarski przyjął z radością wyniki prowadzonych w Rydze rokowań. Pokonanie bolszewików wynikało jego zdaniem z kilku czynników, a wśród nich decydującymi okazały się: ofiarność społeczeństwa, które nie tylko dostarczyło rekruta, ale i poniosło dotkliwe straty ekonomiczne, waleczność żołnierzy oraz mądrość naczelnego dowództwa wojsk polskich podejmującego decyzje przesądzające o zwycięstwie żołnierzy ${ }^{52}$.

Zakończenie wojny oznaczało powrót Polski do budowy instytucji i stabilizacji gospodarki suwerennego państwa. Dla Stolarskiego wiązało się to ze wznowieniem pracy parlamentarnej. Na posiedzeniach plenarnych Sejmu Ustawodawczego zabierał głos szesnaście razy, składając w imieniu klubu oświadczenia polityczne i uczestnicząc w debatach nad projektami ustaw. Warto zauważyć, że przemówienia szefa PSL „Wyzwolenie” odzwierciedlały nie tylko jego poglądy i przekonania, ale przede wszystkim stanowisko partii. Drugą widoczną formą aktywności parlamentarnej Stolarskiego było składanie, samodzielnie lub w grupie posłów, wniosków nagłych dotyczących w większości zagadnień rolnictwa i problemów mieszkańców wsi. Wypełniając mandat poselski, Stolarski otrzymywał wiele skarg i próśb o interwencje w kwestiach lokalnych konfliktów oraz krzywd doznanych przez ludność wiejską od aparatu administracyjnego. Stanowiły one często podłoże składanych przez niego interpelacji będących formą interwencji u premiera lub ministrów rządu. Podejście gospodarza ze Sługocic przypominało $w$ tym względzie postępowanie innych chłopskich posłów podnoszących na forum sejmu problemy z terenu własnego okręgu

so Tenże, Obywatele, Wyborcy!, „Wyzwolenie” I920, nr 33, s. 365.

5I W. Roszkowski, Najnowsza historia Polski I9I4-1939, Warszawa 20II, s. 88-89.

52 SSSU nr I77, 22 X 1920 r., tam 20. 
wyborczego. Wydaje się jednak, że w tym też tkwiła istota postrzegania i wypełniania przez Stolarskiego roli parlamentarzysty, z jednej strony reprezentującego interesy lokalnego społeczeństwa, a z drugiej stojącego na straży dobra publicznego ${ }^{53}$.

\section{Aktywność w samorządzie oraz organizacjach społecznych}

Podobnie jak w okresie I wojny światowej w pierwszych latach niepodległości Stolarski prowadził intensywną działalność w organizacjach rolniczych i spółdzielczych. Wzmocnił swoją pozycję jednego z liderów Centralnego Związku Kółek Rolniczych, wszedł również w skład Zarządu Centrali Spółdzielczych Stowarzyszeń Rolniczo-Handlowych, a swoją wiedzą i doświadczeniem z zakresu rolnictwa dzielił się, pomimo licznych obowiązków służbowych, zarówno z kolegami z kółka rolniczego w Sługocicach, jak i czytelnikami prasy rolniczej ${ }^{54}$.

Równolegle $\mathrm{z}$ aktywnością polityczną oraz pracą $\mathrm{w}$ organizacjach społecznych i gospodarczych na forum ogólnopolskim, Błażej Stolarski prowadził ożywioną działalność w samorządzie powiatu brzezińskiego. Od roku 1919 pełnił funkcję radnego w sejmiku powiatowym w Brzezinach, a w latach I92I-I922 również obowiązki członka wydziału powiatowego. Znalazł się zatem w gronie takich działaczy, jak: Wincenty Witos, Józef Putek, Jakub Bojko, Aleksander Średniawski i Andrzej Czapski, którzy nie zrezygnowali z funkcji radnych w samorządzie, pomimo jednoczesnego piastowania eksponowanych stanowisk we władzach państwowych lub strukturach partyjnych"s.

W kontekście pracy w samorządzie warto wspomnieć o przedsięwzięciu, jakie połączyło więzami przyjaźni pierwszego z ostatnim ministrem rolnictwa II Rzeczypospolitej. Było nim założenie męskiej szkoły rolniczej i fermy w Czarnocinie, których kierownictwo objął Juliusz Poniatowski. Miała to być wspólna inwestycja powiatów łódzkiego i brzezińskiego, a jej głównym orędownikiem w brzezińskim sejmiku powiatowym stał się Błażej Stolarski toczący boje w kwestii wystąpienia o pożyczkę ze Skarbu Państwa i zasiłek z Ministerstwa Rolnictwa i Dóbr Państwowych na budowę szkoły rolniczej. Współpraca zakończyła się sukcesem i otwarcie męskiej szkoły rolniczej w Czarnocinie nastąpiło 24 I 1924 r. ${ }^{56}$

\footnotetext{
53 P. Perzyna, Btażej Stolarski 1880-1939..., s. 135, 138-141.

54 Tamże, s. 186-187.

55 A. Łuczak, Samorząd terytorialny w programach i dziatalności stronnictw ludowych 1918-1939, Warszawa 1973, s. 45; P. Perzyna, Btażej Stolarski - sylwetka..., s. 809.

56 Tenże, Btażej Stolarski I880-1939..., s. 170-I7 I.
} 
W pierwszych latach niepodległości Stolarski kontynuował także działalność oświatową. Pełnił obowiązki głównego opiekuna publicznej szkoły powszechnej w Sługocicach, a pod koniec 1920 r. na osobistą prośbę powiatowego inspektora szkolnego, z uwagi - jak sam zapewniał - na trudną sytuację oświaty w gminie Będków, przyjął nominację na członka miejscowego Dozoru Szkolnego, do zadań którego należała kontrola nad przestrzeganiem obowiązku szkolnego oraz przygotowywanie projektów planów finansowych dla szkół na terenie gminy. Wspomniany organ nadzoru nad oświatą już 6 stycznia następnego roku powierzył mu stanowisko prezesa. W okresie pełnienia tej funkcji (I92I-I922) kierowany przez Stolarskiego dozór przygotował m.in. projekt zmiany sieci oświatowej i wznoszenia gmachów szkolnych w gminie ${ }^{57}$.

Wszystkie zaprezentowane dokonania gospodarza ze Sługocic świadczą niezbicie, że u progu niepodległości wkroczył on do kręgu elity politycznej i władzy Rzeczypospolitej Polskiej. Był to najlepszy okres w jego karierze partyjnej i parlamentarnej. Błażej Stolarski nie miał jednak osobowości przywódcy, wodza i ideologa, gdyż osiągnięcie tego poziomu wymagało charyzmy, błyskotliwości i ugruntowanej poprzez wieloletnią naukę wiedzy. Wspomnianych cech, niestety, nie posiadał. Jego żywiołem stała się przede wszystkim aktywność w sferze społecznej i gospodarczej. Stolarski rozumiał ją i głównie z niej czerpał satysfakcję. To ona gwarantowała mu uznanie w partii oraz rozkwit kariery politycznej w okresie I wojny światowej i w wolnej Polsce, a w konsekwencji udział w budowie prawnych i instytucjonalnych fundamentów państwowości odradzającej się Rzeczypospolitej.

Aktywność społeczna i gospodarcza prezesa PSL „Wyzwolenie”, oprócz inicjowania i prowadzenia przedsięwzięć zmierzających do intensyfikacji rolnictwa i podniesienia poziomu życia na wsi, miała także inny gębszy, państwowotwórczy podtekst. Było nim wychowanie obywatelskie chłopów przygotowujące ich do świadomego i pożytecznego dla ogólnego dobra uczestnictwa w życiu danej społeczności i państwa. Przejawiało się

57 Biblioteka Uniwersytetu Łódzkiego, Oddział Zbiorów Specjalnych, Rękopisy Błażeja Stolarskiego, sygn. 6496, bp., Pismo prezesa Dozoru Szkolnego gminy Będków do powiatowej rady szkolnej z 22 X I92 I r.; tamże, Odpis wniosku uchwalonego na posiedzeniu Dozoru Szkolnego gminy Będków w dniu 7 I 1922 r.; tamże, Wyciąg z protokołu posiedzenia Dozoru Szkolnego gminy Będków w dniu 7 I 1922 r.; Archiwum Państwowe w Piotrkowie Trybunalskim. Oddział w Tomaszowie Mazowieckim, Akta Gminy Będków, sygn. 40, bp., Pismo prezesa Dozoru Szkolnego gm. Będków do rady gminnej w Będkowie z 16 I 1922 r. w sprawie sieci szkolnej; M. Pęcherski, M. Świątek, Organizacja oświaty w Polsce w latach 1917-1977. Podstawowe akty prawne, Warszawa 1978, s. 34 . 
ono m.in. w kształtowaniu w nich postaw przywiązania do niepodległej ojczyzny, przy jednoczesnym zobowiązaniu ich do wypełniania obowiązków wobec państwa w postaci płacenia podatków i danin oraz oddawania rekrutów do wojska. Wspomniane działania Stolarskiego wynikały nie tyle z jego skłonności do moralizatorstwa, ale były efektem niskiego poziomu świadomości społecznej, historycznej i narodowej chłopów. Z drugiej strony warto zauważyć, że idea służby społecznej, wznoszenia się ponad podziały społeczne i polityczne dla dobra kraju świadczyły o postawie gospodarza ze Sługocic jako wysokiej rangi państwowcu. W tym pozytywistycznym nastawieniu tkwił też jego właściwie pojmowany patriotyzm ${ }^{58}$.

Podsumowaniem dokonań Błażeja Stolarskiego w latach wojny i pierwszych trzech miesiącach budowy suwerennej Polski stała się deklaracja programowa odczytana przez niego, jako pierwszego włościanina występującego w polskim Sejmie Ustawodawczym, podczas czwartego posiedzenia Izby w dniu 22 II I9I9 r.:

Narody istnieją, rosną, rozwijają się lub upadają - zależnie od sił i formy swego politycznego ustroju, a także od cnoty i wartości swych obywateli. Toteż będziemy się starali, aby prawa przez nas na tym Sejmie uchwalone gruntowały rozwój wszystkich dobrych czynników w narodzie, aby w Ojczyźnie naszej każdy obywatel mógł dać z siebie jak najwięcej dobra na pożytek całościs”.

Trzeba w tym miejscu podkreślić, że głoszonemu przesłaniu gospodarz pozostał wierny do końca istnienia II Rzeczypospolitej.

\section{Bibliografia}

\section{Źródła archiwalne}

Archiwum Akt Nowych Centralne Towarzystwo Rolnicze

Archiwum Państwowe w Krakowie Naczelny Komitet Narodowy

Archiwum Państwowe w Łodzi Zbiór druków i pism ulotnych

Archiwum Państwowe w Piotrkowie Trybunalskim. Oddział w Tomaszowie Mazowieckim Akta Gminy Będków

Archiwum Zakładu Historii Ruchu Ludowego Frankowski T., Próby opanowania ruchu chtopskiego przez Narodową Demokrację w Królestwie Polskim. Narodowy Związek Chtopski, Warszawar961, maszynopis. 
PaWet Perzyna Praca dla Polski. Działalność niepodległościowa oraz udział Błażeja Stolarskiego...

Biblioteka Uniwersytetu Łódzkiego, Oddział Zbiorów Specjalnych

Rękopisy Błażeja Stolarskiego

Zespół Szkolno-Gimnazjalny w Będkowie

Goliński W., Kronika szkolna 7. klasowej Szkoty Powszechnej w Będkowie, gm. Będków, pow. brzeziński Okręgu Szkolnego Eódzkiego, [b.m.], rękopis.

\section{Źródła drukowane}

Dąbrowska M., Dzienniki, t. I, Warszawa 1997.

Dziennik Praw Państwa Polskiego 1919

„Polak" 1916

„Przewodnik Kółek i Spółek Rolniczych w Królestwie Polskim” 1917

Sprawozdania stenograficzne posiedzeń Sejmu Ustawodawczego 1919, 1920

„Wyzwolenie” 1918, 1919, 1920, 1935, 1936

\section{Opracowania}

Badziak K., W oczekiwaniu na przetom. Na drodze od odrodzenia do zatamania państwa polskiego: listopad IgI8-czerwiec Ig20, Łódź 2004.

Bogusławski A., Ruch ludowy w czasie wojny 19I4-1918 w Królestwie Polskim w świetle wspomnień, „Roczniki Dziejów Ruchu Ludowego” 1959, nr I.

Borkowski J., Ludowcy w II Rzeczypospolitej, cz. I, Warszawa 1987.

Giza S., Btażej Stolarski 1880-1939, [w:] Przywódcy ruchu ludowego. Szkice biograficzne, red. A. Więzikowa, Warszawa 1968.

Holzer J., Molenda J., Polska w pierwszej wojnie światowej, Warszawa 1967.

Honowski F., Parlament i rząd w Polsce niepodlegtej. Część prawno-polityczna. Stowo wstępne, rok 1918 , Warszawa 1938.

Honowski F., Prawno-polityczne dążenia wsi polskiej na tle literatury ludowej: rok 1918-1938, Warszawa 1939.

Kisielewski T., Heroizm i kompromis. Portret zbiorowy dziataczy ludowych, cz. 2, Warszawa 1979.

Klimek J., Park Amunicyjny Legionów Polskich w Eodzi, „Niepodległość” 1934, t. 9.

Konefał J., Aleksander Zawadzki - „Ojciec Prokop” (1859-1926), „Roczniki Dziejów Ruchu Ludowego" 1986, nr 26.

Łuczak A., Samorzad terytorialny w programach i dziatalności stronnictw ludowych 1918-1939, Warszawa 1973.

Marszałek P.K., Najwyższe wtadze wojskowe w systemie ustrojowym II Rzeczypospolitej, Wrocław $201 \mathrm{I}$.

Marszałek P.K., Rada Obrony Państwa z Ig2o roku. Studium prawno historyczne, „Acta Universitatis Wratislaviensis", nr 2758, Prawo CCXCIV, Wrocław 1995.

Mieczkowski A., Btażej Stolarski 1880-1939. Życie, dziatalność, poglady, Lublin 1998.

Molenda J., Polskie Stronnictwo Ludowe w Królestwie Polskim IgIs-I9I8, Warszawa 1965.

Paczkowski A., Wincenty Witos, premier rzadu polskiego 24 VII Ig20-I3 IX Ig2I, 28 V-I4 XII 1923, IO V-I4 V I926, [w:] Prezydenci i premierzy Drugiej Rzeczypospolitej, red. A. Chojnowski, P. Wróbel, Wrocław 1992.

Pająk J., O rząd i armię. Centralny Komitet Narodowy (I9IS-19I7), Kielce 2003.

Pajewski J., Odbudowa państwa polskiego 19I4-19I8, Warszawa 1985.

Perzyna P., Btażej Stolarski I880-1939. Biografia spotecznika, dziatacza gospodarczego ipolityka, Łódź-Warszawa 2017.

Perzyna P., Btażej Stolarski. Droga do awansu cywilizacyjnego chtopa polskiego w latach I900-19I8, „Acta Universitatis Lodziensis. Folia Historica” 1997, t. 60.

Perzyna P., Btażej Stolarski - sylwetka dziatacza wszechstronnego, „Roczniki Dziejów Ruchu Ludowego" 2018, $\mathrm{nr} 37$. 
PaWet perzyna Praca dla Polski. Działalność niepodległościowa oraz udział Błażeja Stolarskiego...

Pęcherski M., Świątek M., Organizacja oświaty w Polsce w latach 1917-1977. Podstawowe akty prawne, Warszawa 1978.

Roszkowski W., Najnowsza historia Polski 1914-1939, Warszawa 201 I.

Samuś P., Życie polityczno-spoteczne, [w:] Łódź. Dzieje miasta, t. I, red. B. Baranowski i J. Fijałek, Warszawa-Łódź 1988.

Socha J., Btażej Stolarski (I880-1939). Szkic do biografii, [w:] Z dziejów ruchu ludowego w regionie tódzkim, red. W. Piątkowski, Warszawa 1992.

Stolarski B., Chtop a reformy rolne, Warszawa 1919.

Stolarski B., Dziatacz spoteczny na wsi, „Wyzwolenie” 1936, nr 30.

Stolarski B., Dziatacz spoteczny na wsi, „Wyzwolenie” 1936, nr 31 .

Stolarski B., Jakie winno być wspótdziatanie wójta i pisarza, „Wyzwolenie” 1918, nr 57.

Stolarski B., Kilka uwag o naszej gminie, „Wyzwolenie” 1918, nr 35.

Stolarski B., Obywatele, Wyborcy!, „Wyzwolenie” 1920, nr 33.

Stolarski B., Orka, „Wyzwolenie” 1935, nr 26.

Stolarski B., Po wyborach, „Wyzwolenie” 1919, nr 5.

Stolarski B., Stugocice. Obraz życia i pracy jednej wioski, Warszawa 1925.

Stolarski F., Towarzystwo „Uczelnia Polska” im. Kościuszki w Będkowie, „Roczniki Dziejów Ruchu Ludowego" 1972 , $\mathrm{nr}$ I4.

Stolarski B., Związek drobnych rolników, „Przewodnik Kółek i Spółek Rolniczych w Królestwie Polskim" 1917, nr 7.

Thugutt S., Autobiografia, Warszawa 1984.

Zieliński H., Historia Polski 1914-1939, Wrocław 1982.

Streszczenie: Celem artykułu jest omówienie udziału Błażeja Stolarskiego w budowie zrębów niepodległej Rzeczypospolitej w okresie I wojny światowej i kadencji Sejmu Ustawodawczego, na trzech uzupełniających się płaszczyznach aktywności. Pierwsza odnosi się do działalności konspiracyjnej oraz rozwoju kariery politycznej i parlamentarnej Stolarskiego, członka Polskiej Organizacji Wojskowej, Tymczasowej Rady Stanu Królestwa Polskiego, ministra rolnictwa w rządzie Jędrzeja Moraczewskiego, a także prezesa Polskiego Stronnictwa Ludowego „Wyzwolenie” i szefa jego frakcji parlamentarnej. Drugi obszar jego zainteresowań, szczególnie istotny w momencie odbudowy tożsamości narodowej i instytucji suwerennego państwa, odnosi się do kwestii związanych z szerzeniem oświaty w społeczeństwie, tworzeniem na wsi szkół i bibliotek oraz rozwojem samorządu powiatowego. Trzecia sfera zaangażowania Błażeja Stolarskiego wiąże się z jego pracą w organizacjach społecznych i gospodarczych, w szczególności w Centralnym Związku Kółek Rolniczych. Aktywność na tym ostatnim polu miała głębszy państwowotwórczy podtekst, sprowadzający się do kształtowania wśród chłopów postaw przywiązania do niepodległej ojczyzny przy jednoczesnym zobowiązaniu ich do wypełniania obowiązków wobec państwa.

Słowa klucze: Błażej Stolarski, I wojna światowa, niepodległość

Summary: The aim of the article is to present Błażej Stolarski's participation in the creation of basis of an independent republic during World War I and the term of office of the Legislative Parliament on three complementary levels of activity. The first one refers to the conspiratorial activity and the development of political and parliamentary career of Stolarski as a member of the Polish Military Organisation and of the Provisional Council of State of the Kingdom of Poland, the Minister of Agriculture in the government of Jędrzej Moraczewski, as well as the president of the Polish People’s Party "Wyzwolenie" 
PaWet Perzyna Praca dla Polski. Działalność niepodległościowa oraz udział Błażeja Stolarskiego...

['Liberation'] and the head of its parliamentary faction. The second area of his interest, particularly relevant at the time of the reconstruction of the national identity and the institution of a sovereign state, concerns the issues related to the spread of education in society, the establishment of schools and libraries in the countryside and the development of district self-government. The third sphere of Błażej Stolarski's involvement is related to his work in social and economic organisations, in particular in the Central Association of Agricultural Societies. Activity in the latter field had a deeper state-forming subtext, which came down to the formation of attitudes of attachment to an independent homeland among peasants, while obliging them to fulfil their state obligations.

Keywords: Błażej Stolarski, World War I, independence 